\title{
Psychological Empowerment, Emotional Intelligence and Professional Behavior among Nurse Interns
}

\author{
Hind Abdullah Mohamed ${ }^{1}$ Amal Sobhy Mahmoud ${ }^{2}$ Salwa Ahmed mohamed ${ }^{3}$ \\ ${ }^{1}$ Lecturer of Nursing Administration, Faculty of Nursing, Port Said University, Egypt. \\ ${ }^{2}$ Assistant Prof. Psychiatric and Mental Health Nursing, Faculty of Nursing, Port Said University, Egypt. \\ ${ }^{3}$ Lecturer of Nursing Administration, Faculty of Nursing, Beni Suef University, Egypt.
}

\begin{abstract}
Background: Nursing is a profession requiring prolonged training and a formal qualification. Therefore, nurse interns are expected to display competent and skillful behaviors in alignment with their profession.

Aim: This study aimed to investigate the relationship between psychological empowerment, emotional intelligence and professional behavior among nurse interns.

Material and methods: A comparative correlation research design was utilized with a sample of 200 nurse interns affiliated to Port-Said University and Mansoura University during the academic year 2014/2015. Data was collected from February to April 2015.

Tools of data collection: Personal and job characteristics of the participants, psychological empowerment scale, emotional intelligence questionnaire and nursing students professional behaviors scale (NSPBS).

Results: The study findings revealed that the majority of the nurse interns in both faculties had high psychological empowerment level (85\%), whereas $93.3 \%$ of them in Port-Said were highly empowered compared to $78.4 \%$ in El-Mansoura with a statistically significant difference. $69.0 \%$ of nurse interns have an acceptable level of emotional intelligence, most of them (76.6\%) from El Mansoura. $86.5 \%$ of nurse interns in Port-Said reflected a high level of professional behavior, while less than two thirds of nurse interns in El Mansoura behaved professionally. The significant positive relation was found between the psychological empowerment, emotional intelligence and professional behavior in both settings.

Conclusion: The study concluded that professional behavior is related to emotional intelligence and psychological empowerment. Nurse interns need to push forward from acceptable level of emotional intelligence to a high level to be more effective and enhance their professional behavior and performance.
\end{abstract}

Keywords: Psychological empowerment, emotional intelligence, professional behavior, nurse interns.

\section{Introduction}

The internship is an essential stage, while the student nurses are new and they are as transparent materials. The internship is a real opportunity that enables students to apply their insight to this present reality. The experience will not only help them to develop their skills needed to work but working on real projects for a real organization will also give them the interpersonal abilities that they have to work viably with others, confidence, and trust in their own particular capacities ${ }^{[1]}$.

Internship is the possibility to build the certainty and critical thinking of nurse interns, to enhance knowledge, skills, and clinical competence, and to lessen stress and tension ${ }^{[2,3]}$. Also, internship will empower nurse interns to work closely and develop professional working relationships, it permits nurse interns to investigate every one of the potential outcomes and gain an unforgettable life experience, internship year assumes a key part in preparing nurse interns for the profession of nursing ${ }^{[1]}$.

To accomplish the expert state of the professional attitude and behavior through nursing labor, empowerment is a vital key to competency and accomplishment, for medicinal services associations and for health care organizations ${ }^{[4]}$. Additionally, to provide the desired services in hospitals, nurses and health care providers should be empowered ${ }^{[5]}$. Recently, the concept of empowerment has been very influential in the management and nursing profession ${ }^{[6]}$. Nursing confronts challenges with developing psychological empowerment across the discipline; these challenges are as a result of a history of professional servility and being an underdeveloped resource in the health care system ${ }^{[7]}$. Moving from empowerment in terms of management to subordinates' perception is called cognitive and psychological empowerment ${ }^{[8]}$.

Psychological empowerment mean the way a person perceives himself or herself at the workplace and the degree to which a person would be able to form his work role ${ }^{[9] .}$ As indicated by Spreitzer, psychological empowerment has four dimensions: meaning involves a fit between the needs of one's work role and one's beliefs, values, and behaviors, competence denotes to self-efficacy particular to one's work, or a belief in one's capability to perform work activities skillfully, self-determination refers to a sense of choice in initiating and regulating one's actions, it reflects the person's sense of autonomy or decision over the start and continuation of 
work behavior and processes, and the impact is the degree to which one can influence strategic, administrative, or operating outcomes at work ${ }^{[10]}$.

Psychological empowerment is a motivational process in which persons feel themselves as more capable independent and confident, and it is a process of granting greater autonomy and basic leadership is given to somebody as having skill or polished methodology in the field of work, and the whole process will help the person to optimize their performance in conducting tasks, along with greater responsibility offered ${ }^{[9,11]}$. Furthermore, ${ }^{[12]}$ states that empowerment is important in a way that it can make nurses do things that they could not do before, including the capacity to perceive feelings, manage emotions, motivate oneself, recognize emotions in others, and to build relationships with others, that is known as emotional intelligence ${ }^{[13]}$.

Emotional intelligence (EI) is portrayed as the ability to get ideal results from relationships with others ${ }^{[14]}$. It is fundamental to be considered in an organizational setup ${ }^{[15]}$. EI refers to the ability to adaptively perceive, understand, regulate and harness emotion in oneself and other's ${ }^{[16]}$. Also, it is defined as the capacity for recognizing our own feelings and those of others, for motivating ourselves, and for managing our emotions well and our relationships. Furthermore, EI consisted of five general parts viz; self-awareness, self-regulation, motivation, empathy, and social skills ${ }^{[17] .}$

Self- awareness means the individuals' ability to recognize and understand one's moods, emotions and drives as well as their effect on others, self-regulation refers to the ability to control or redirect disruptive impulses or moods as well as the propensity to suspend judgment, motivation is the use of deepest preference to move and guide toward achieving goals, empathy means sensing what others are feeling, being able to take their perspective, and social skills is the proficiency in handling relationships and building networks; an ability to find common ground ${ }^{[14,17]}$. According to ${ }^{[18]}$ emotional intelligence is considered these days the strongest indicator of success and achievement in the work place.

When nurse internes had the abilities to evaluate themselves and management, they are named as 'professionals' who achieve the trust and respect of the society. Nursing is a profession existing as a community service from the ancient history that has originated from the desire of making humans healthy and comfortable, taking care of ill people and evoking the feeling that the patient is safe ${ }^{[19,20]}$. The nursing profession demands individual to be self-directed, responsible, accountable, and behave in a professional manner which is shaping nurses values, skills, and attitudes that directly affect subsequent patient care and management ${ }^{[21]}$.

Professionals, know about their own roles and responsibilities, behave autonomously, think critically, make their own decisions, respect individuals and are sensitive to the ethical values of the profession in the system to achieve optimal outcomes in professional tasks and interactions ${ }^{[22,23]}$. In another definition, professionals are characterized as people who that would show able and handy practices in alignment with their profession ${ }^{[19]}$. A professional practice behavior refers to registered nurses' and nursing students' reports of professional autonomy ${ }^{[24]}$. In addition, individual performance is not only about doing tasks perfectly but also about the ability to control and manage oneself as well as about the ability to build relationships with others. These capabilities, called emotional intelligence which determines personal patterns of interaction and the quality of the relationships developed ${ }^{[25,26]}$.

\section{Significance of study:}

At the point when a nursing student graduates from instructive educational program, the health care organizations and communities, assume that the new practitioner has the intellectual, psychomotor, and behavioral skills necessary to provide competent skillful care. In addition to a core of cognitive information and psychomotor skills, it has been recognized by educators and practicing professionals that a repertoire of behaviors is required for success in any given profession. No trial was done to investigate the relation between psychological empowerment, emotional intelligence, and professional behavior among nurse interns. So, we hope that this study will help to understand these relations among nurse interns.

\section{This study aimed to:}

Investigate the relationship between psychological empowerment, emotional intelligence, and professional behavior among nurse interns.

\section{Research Objectives:}

1-Assay the psychological empowerment levels among nurse interns.

2- Determine the levels of emotional intelligence among nurse interns.

3- Assess the nurse interns' levels of professional behaviors.

4-Find out the relationship between psychological empowerment, emotional intelligence, and professional behavior among nurse interns. 


\section{Study design:}

\section{Subject And Methods}

A comparative correlational research design was utilized.

\section{Setting:}

The study was carried out in two governmental nursing faculties affiliated to Ministry of Higher Education, namely: Faculty of Nursing, Port-Said University, which was established in 1991 and adopted problem based learning approach and Faculty of Nursing, Mansoura University which was established in 1992 and adopted traditional teaching approach. According to the internship distribution plan by the two mentioned faculties, the participants were selected from hospitals in Port-Said city (Port Said general hospitals) and Mansoura city (Mansoura university hospitals).

\section{Subject:}

The sample of this study consisted of convenience nurse interns at the academic year 2014/2015 from two nursing faculties, Port-Said University and Mansoura University, who had the following inclusion criteria, available at the time of data collection, accepted to participate in the study and having at least six months of the internship year. The total number was (200) nurse interns, 89 nurse interns for Port-Said University with response rate $95 \%$ and 111 nurse interns for Mansoura University with response rate $62 \%$.

\section{Tools of data collection:}

The tools used to collect the data for this study were divided into four sections; which are personal and job characteristics for the participants, psychological empowerment scale, emotional intelligence questionnaire, and nursing students professional behaviors scale (NSPBS).

\section{Section (1): Personal and Job Characteristics for the Participants:}

This part was developed by the researcher and includes data related to the personal and job characteristics of the studied sample such as age, sex, marital status and faculty name.

Section (2): Psychological Empowerment Scale:

The scale is a 12 -item, created by ${ }^{[27]}$, which was utilized to measure psychological empowerment.

\section{Scoring System:}

Response options ranged from (1) "strongly disagree" to (7) "strongly agree". To estimate the cut off point, the median was calculated (58) and divided by the total score of psychological empowerment (84) giving a result (0.691); these scores were converted into a percentage score (cut off point $69 \%$ ). The subject was considered empowered if the percentage score was $69 \%$ or more and not empowered if less than $69 \%$ [28].

\section{Section (3): Emotional Intelligence Questionnaire:}

This instrument developed by ${ }^{[29] .}$. It was used to evaluate the nurse interns' emotional intelligence. It consists of 15 items that were categorized under 5 domains: self- awareness, self-regulation, self- motivation, empathy, and social skills. Each domain contains three items.

\section{Scoring System:}

Nurse interns' reactions and responses were measured on a five point Likert scale specifically; very often (5), often (4), sometimes (3), rarely (2) and not at all (1). Questions numbered 4, 6, 7, 8, 11, 14 and 15 had reversed score. For each domain, the scores of the items were summed-up and the total was divided by the number of the items, giving a mean score for each part. The levels of emotional inelegance were divided as $15-$ 34 considered low worthy level of emotional intelligence, $35-55$ is acceptable level and $56-75$ represents high level of emotional intelligence.

\section{Section (4): Nursing Students Professional Behaviors Scale (NSPBS):}

This Scale was created by ${ }^{[30] .}$ It is used to assess the nurse interns' levels of professional behaviors. It comprises 27 items regarding professional behaviors.

\section{Scoring System:}

Nurse interns' responses were measured on a five point Likert scale namely; absolutely sufficient (5), partially sufficient (4), undecided (3), insufficient (2) and absolutely insufficient (1). The points that can be scored on the scale fluctuate between 27 and 135. According to cut off points, the subject was considered 
behaving with professional manner (high level) if the percentage score was 60\% or more and not behaving professionally (low level) if less than $60 \%$.

\section{Methods}

- The psychological empowerment scale, emotional intelligence questionnaire, and nursing students professional behaviors scale translated into Arabic by the researchers, and the Arabic version was translated again into English by a bilingual professional person, and the three versions compared. The three tools were checked for face and content validity by five teaching staff in the field of Nursing Administration and Psychiatric Nursing. Accordingly, needed modification was done.

- The reliability of the tools was done using Alpha Cronbach's test, which indicated that the tool is reliable through the values of the test which were 0.81 for psychological empowerment, 0.86 for emotional intelligence, and 0.95 for professional behavior.

\section{Pilot study:}

A pilot study was carried out on twenty nurse interns who were selected randomly before starting data collection, to ascertain the clarity and applicability of the tools. Needed modifications were done based on analysis of the pilot results. Those nurse interns who shared in the pilot study were excluded from the main study sample.

\section{Ethical considerations:}

Written approval was obtained from the Dean of the two Faculties of Nursing. Also an approval was taken from medical and nursing directors of the studied hospitals to collect necessary data and verbal consent was obtained from the nurse interns before distributing the questionnaires and after explanation of the purpose of the study; anonymity was assured and maintained; no burden or risk was imposed on participants; no coercion or pressure was applied. Nurse interns were assured about the confidentiality of the data gathered and it was only for the purpose of the study and informed about their right to refuse to participate in the study or withdraw at any time.

\section{Field work:}

According to the internship distribution plan, the researchers met the nurse interns according to their schedule in the morning shift and distribute the study tool for them and some of them filled the tools in the time of distribution and others gave some other time to return it. The time of the data collection lasted for three months from February to April 2015.

\section{Data analysis}

Data was coded, computerized and then analyzed using the Statistical Package for Social Science (SPSS) software package version 20.0.Using frequency \& percentage for qualitative data, mean and standard deviation for quantitative data, $\chi^{2} \mathrm{~T}$ Test and Pearson coefficient correlation were used, statistical significance was considered at the 0.05 level.

\section{Results}

A study result indicates that $66 \%$ of participants were females and $77 \%$ of the intern nurses were in the age group from 21 to less than 23 years. The majority of them were unmarried. Psychological empowerment levels among nurse internes in the two faculties are displayed in table (1). According to the table, it was found that the majority of the nurse internes in both faculties had high psychological empowerment level (85\%), whereas $93.3 \%$ of them in Port-Said were highly empowered compared to $78.4 \%$ in El-Mansoura with a statistically significant difference. According to emotional intelligence levels among intern nurses table (2), shows that only $28.5 \%$ of all participants had high level of emotional intelligence, $34.8 \%$ of them are nurse interns in Port Said, while 23.4\% from El Mansoura. About two thirds of nurse interns (69.0\%) have acceptable level of emotional intelligence, most of them (76.6\%) from El Mansoura with a highly statistically significant difference $\left(\chi^{2}=10.357, \mathrm{p}=.004\right)$. Table (3): displays mean and standard deviation of emotional intelligence domains among nurse interns. With regard to five domains, it was found that the order of the domains from highest mean scores to lowest one are social skills, self-awareness, empathy, self- regulation and selfmotivation domain $(73.92 \pm 19.93,69.17 \pm 19.11,59.46 \pm 17.74,56.29 \pm 18.82,50.08 \pm 20.03$ respectively). The difference between the mean scores among nurse interns in both faculties was humble. The only significant relation was observed related to self- regulation domain $\left(\mathrm{t}=1.980^{*}\right.$ with a $\mathrm{P}$ value of $\left.0.049^{*}\right)$. Intern nurses' professional behaviors level was shown in table (4), it was declared that, the highest percentage $(86.5 \%)$ of nurse interns in Port Said reflected the high level of professional behavior, while less than two thirds of nurse interns (64.9\%) in El Mansoura behaved professionally. Statistically significant difference was found between 
both settings $\left(\chi^{2}=12.189, \mathrm{p}=.001\right)$.Table (5), demonstrates a correlation between psychological empowerment, emotional intelligence and professional behaviors among intern nurses in Port Said and El Mansoura, the table reveals significant positive relations between professional behaviors and (psychological empowerment and emotional intelligence) among Port Said intern nurses. Meanwhile, no relation was detected between psychological empowerment and emotional intelligence. On the other hand, it was found a positive significant relation between psychological empowerment, emotional intelligence and professional behaviors among Mansoura intern nurses. Regarding a correlation matrix between the three variables among the studied participants in both faculties, table (6) clarifies the positive significant relation between psychological empowerment, professional behaviors, and emotional intelligence domains.

Table (1): Distribution of the intern nurses according to their psychological empowerment levels $(n=200)$.

\begin{tabular}{|c|c|c|c|c|c|c|c|c|}
\hline \multirow[t]{2}{*}{$\begin{array}{l}\text { Psychological empowerment } \\
\text { levels }\end{array}$} & \multicolumn{2}{|c|}{$\begin{array}{c}\begin{array}{c}\text { Port said } \\
(n=89)\end{array}\end{array}$} & \multicolumn{2}{|c|}{$\begin{array}{l}\begin{array}{c}\text { EI Mansoura } \\
(n=111)\end{array} \\
\end{array}$} & \multicolumn{2}{|c|}{$\begin{array}{c}\begin{array}{c}\text { Total } \\
(\mathbf{n}=\mathbf{2 0 0})\end{array} \\
\end{array}$} & \multirow{2}{*}{$\chi^{2}$} & \multirow{2}{*}{$\mathbf{p}$} \\
\hline & No. & $\%$ & No. & $\%$ & No. & $\%$ & & \\
\hline $\begin{array}{l}\text { Less than 69\% } \\
\text { (Not empowered) }\end{array}$ & 6 & 6.7 & 24 & 21.6 & 30 & 15.0 & \multirow{2}{*}{$8.578^{*}$} & \multirow{2}{*}{$0.003 *$} \\
\hline $\begin{array}{l}\text { 69\% or more } \\
\text { ( Empowered) }\end{array}$ & 83 & 93.3 & 87 & 78.4 & 170 & 85.0 & & \\
\hline
\end{tabular}

Table (2): Distribution of the intern nurses according to their emotional intelligence levels $(n=200)$ :

\begin{tabular}{|c|c|c|c|c|c|c|c|c|}
\hline \multirow[t]{2}{*}{$\begin{array}{c}\text { Emotional intelligence } \\
\text { levels }\end{array}$} & \multicolumn{2}{|c|}{$\begin{array}{c}\text { Port said } \\
(n=89)\end{array}$} & \multicolumn{2}{|c|}{$\begin{array}{c}\begin{array}{c}\text { El Mansoura } \\
(n=111)\end{array} \\
\end{array}$} & \multicolumn{2}{|c|}{$\begin{array}{c}\text { Total } \\
(\mathbf{n}=\mathbf{2 0 0})\end{array}$} & \multirow{2}{*}{$\chi^{2}$} & \multirow{2}{*}{$\mathbf{p}$} \\
\hline & No. & $\%$ & No. & $\%$ & No. & 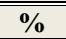 & & \\
\hline "Low level & 5 & 5.6 & 0 & 0.0 & 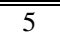 & 2.5 & \multirow{3}{*}{$10.357^{*}$} & \multirow{3}{*}{$0.004 *$} \\
\hline Acceptable level & 53 & 59.6 & 85 & 76.6 & 138 & $\begin{array}{l}69.0 \\
\end{array}$ & & \\
\hline High level & 31 & 34.8 & 26 & 23.4 & $\overline{c 57}$ & 28.5 & & \\
\hline
\end{tabular}

$\chi^{2}:$ Chi square test $\quad *$ : Statistically significant at $\mathrm{p} \leq 0.05$

Table (3): Mean and standard deviation of emotional intelligence domains among intern nurses ( $n=200$ ).

\begin{tabular}{|l||c|c|c||c||c||}
\hline \hline \multirow{2}{*}{$\begin{array}{c}\text { Emotional intelligence } \\
\text { domains }\end{array}$} & $\begin{array}{c}\text { Total } \\
(\mathbf{n = 2 0 0})\end{array}$ & $\begin{array}{c}\text { Port said } \\
(\mathbf{n = 8 9})\end{array}$ & $\begin{array}{c}\text { El Mansoura } \\
(\mathbf{n = 1 1 1})\end{array}$ & t & p \\
\cline { 2 - 5 } & Mean \pm SD & Mean \pm SD & Mean \pm SD & \\
\hline \hline Self-awareness & $69.17 \pm 19.11$ & $69.01 \pm 23.37$ & $69.26 \pm 14.95$ & 0.100 & 0.920 \\
\hline \hline Self-regulation & $56.29 \pm 18.82$ & $53.37 \pm 20.09$ & $58.63 \pm 17.48$ & $1.980^{*}$ & $0.049^{*}$ \\
\hline \hline Self- motivation & $50.08 \pm 20.03$ & $52.81 \pm 22.79$ & $47.90 \pm 17.32$ & 1.681 & 0.095 \\
\hline \hline Empathy & $59.46 \pm 17.74$ & $61.24 \pm 21.47$ & $58.03 \pm 13.99$ & 1.216 & 0.226 \\
\hline \hline Social skills & $73.92 \pm 19.93$ & $74.16 \pm 24.07$ & $73.72 \pm 15.98$ & 0.146 & 0.884 \\
\hline \hline
\end{tabular}

T: Student t-test $\quad$ *statistically significant at $\mathrm{p} \leq 0.05$

Table (4): Distribution of the intern nurses according to their professional behaviors levels ( $n=200)$.

\begin{tabular}{|c|c|c|c|c|c|c|c|c|}
\hline \multirow{2}{*}{$\begin{array}{c}\text { Professional } \\
\text { behaviors levels }\end{array}$} & \multicolumn{2}{|c|}{$\begin{array}{c}\begin{array}{c}\text { Port said } \\
(\mathrm{n}=89)\end{array} \\
\end{array}$} & \multicolumn{2}{|c|}{$\begin{array}{c}\text { El Mansoura } \\
(\mathbf{n}=111)\end{array}$} & \multicolumn{2}{|c|}{$\begin{array}{c}\text { Total } \\
(\mathbf{n}=\mathbf{2 0 0})\end{array}$} & \multirow[t]{2}{*}{$\chi^{2}$} & \multirow[t]{2}{*}{$\mathbf{p}$} \\
\hline & No. & $\%$ & No. & $\%$ & No. & $\%$ & & \\
\hline $\begin{array}{l}\text { Less than 60\% } \\
\text { (low level) }\end{array}$ & 12 & 13.5 & 39 & 35.1 & 51 & 25.5 & \multirow[b]{2}{*}{$12.189^{*}$} & \multirow[b]{2}{*}{$<0.001 *$} \\
\hline $\begin{array}{c}60 \% \text { or more } \\
(\text { high level })\end{array}$ & 77 & 86.5 & 72 & 64.9 & 149 & 74.5 & & \\
\hline
\end{tabular}

$\chi^{2}$ : Chi square test

*: Statistically significant at $\mathrm{p} \leq 0.05$ 
Table (5): Correlation between psychological empowerment, emotional intelligence and professional behaviors among intern nurses in Port Said and Mansoura.

\begin{tabular}{|c|c|c|c|c|c|}
\hline \multirow{2}{*}{\multicolumn{2}{|c|}{ Study variables }} & \multicolumn{2}{|c|}{ Port- Said (n = 89) } & \multicolumn{2}{|c|}{ Mansoura (n=111) } \\
\hline & & $\begin{array}{l}\text { Psychological } \\
\text { empowerment }\end{array}$ & $\begin{array}{c}\text { Professional } \\
\text { behaviors }\end{array}$ & $\begin{array}{l}\text { Psychological } \\
\text { empowerment }\end{array}$ & $\begin{array}{c}\text { Professional } \\
\text { behaviors }\end{array}$ \\
\hline \multirow{2}{*}{ Professional behaviors } & $\mathbf{r}$ & $0.220 *$ & & $0.876 *$ & \\
\hline & $\mathbf{p}$ & $0.038 *$ & & $<0.001^{*}$ & \\
\hline \multirow{2}{*}{ Emotional intelligence } & $\mathbf{r}$ & 0.014 & $0.459 *$ & $0.357 *$ & $0.540 *$ \\
\hline & $\mathbf{P}$ & 0.899 & $<0.001 *$ & $<0.001 *$ & $<0.001^{*}$ \\
\hline
\end{tabular}

Table (6): Correlation matrix between psychological empowerment, professional behaviors and emotional intelligence domains in the total sample $(n=200)$.

\begin{tabular}{|c|c|c|c|}
\hline \multicolumn{2}{|c|}{ Study variables } & \multirow{2}{*}{$\begin{array}{c}\begin{array}{c}\text { Psychological } \\
\text { empowerment }\end{array} \\
0.697^{*}\end{array}$} & \multirow[t]{2}{*}{ Professional behaviors } \\
\hline \multirow{2}{*}{ Professional behaviors } & $\mathbf{r}$ & & \\
\hline & $\mathbf{p}$ & $<0.001^{*}$ & \\
\hline \multirow{2}{*}{ Self-awareness } & $\mathbf{r}$ & $0.281^{*}$ & $0.343^{*}$ \\
\hline & p & $<0.001^{*}$ & $<0.001^{*}$ \\
\hline \multirow{2}{*}{ Self- regulation } & $\mathbf{r}$ & $-0.158 *$ & 0.072 \\
\hline & p & $0.025^{*}$ & 0.312 \\
\hline \multirow{2}{*}{ Self- motivation } & $\mathbf{r}$ & -0.009 & $0.200^{*}$ \\
\hline & p & 0.903 & $0.005^{*}$ \\
\hline \multirow{2}{*}{ Empathy } & $\mathbf{r}$ & $0.222^{*}$ & $0.427^{*}$ \\
\hline & $\mathbf{p}$ & $0.002^{*}$ & $<0.001^{*}$ \\
\hline \multirow{2}{*}{ Social skills } & $\mathbf{r}$ & $0.266^{*}$ & $0.542^{*}$ \\
\hline & $\mathbf{p}$ & $<0.001^{*}$ & $<0.001^{*}$ \\
\hline \multirow{2}{*}{ Total Emotional intelligence } & $\mathbf{r}$ & $0.172 *$ & $0.456^{*}$ \\
\hline & p & $0.015^{*}$ & $<0.001^{*}$ \\
\hline
\end{tabular}

r: Pearson coefficient

*: Statistically significant at $\mathrm{p} \leq 0.05$

\section{Discussion}

Nursing graduates in the internship period, go through a critical experience of transitioning from an instructive educational program to a work setting. This time has been generally accompanied by stress, role change, and reality stun or shock. In spite of the fact that there are a lot of difficulties and challenges

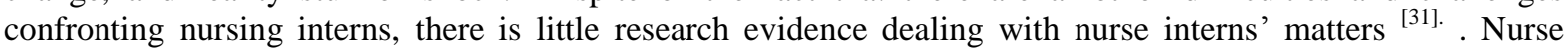
interns need to be empowered to fulfill their role within the standards espoused by the nursing profession and the dynamics of an evolving healthcare system that is flooded with service delivery challenges ${ }^{[32]}$.

The present research indicated that the majority of intern nurses perceived psychological empowerment as the high level that may lead to the achievement of excellence in the nursing profession. This might be attributed to nurse interns in the two faculties feel themselves more independent and confidante persons. This is a similar view of ${ }^{[33]}$ who asserted, that empowerment is fundamentally a motivational process in which individuals feel themselves as more capable independent skilled and confident care giver. Likewise, [9] expressed that psychological empowerment described as the way a man sees himself or herself at the environment of work place and the degree to which a person would be able to form a work role. In this context, ${ }^{[34]}$ asserted that the empowered staff nurses must have effective role independence, and autonomy.

Nurses who perceive themselves to be psychologically empowered will probably upgrade and enhance client care through more effective work practice and give better levels of care ${ }^{[35]}$. Additionally, ${ }^{[36,37]}$ proved that the psychological empowerment has been seen as having the capacity to assume a key role in the professional development, increasing nurses' job satisfaction, giving a better quality for patients and included the sense of meaning, self-determination, competence thus work methods and outcomes could be improved. 
This outcome conflicting with ${ }^{[38]}$ that studied nurses' psychological empowerment at Menofia Governorate/Egypt and found declined level of psychological empowerment. Otherwise, ${ }^{[39]}$ found that nurses in Iran social security organization hospitals considered their empowerment status at a direct moderate level.

The study results revealed that high level of emotional intelligence was observed within Port Said intern nurses than their peers in Mansoura that may be related to the nontraditional method of teaching problem based learning (problem solving) adopted by the faculty of nursing in Port Said. Problem solving is a cognitive mentally processing directed at transforming a given situation into a goal situation when no obvious method of solution is available to the problem solver ${ }^{[40]}$. According to the theory of Salovey, and Mayer $(1990,1997)$ conceptualize emotional intelligence as a form of pure intelligence consisting of cognitive capacity just ${ }^{[41]}$. The present study point of view is upheld and supported by ${ }^{[42]}$ who studied emotional intelligence and problem solving strategy in Iran, and concluded that, there was significant relation between emotional intelligence and problem solving strategies, that the students with high emotional intelligence used problem solving strategy than with low emotional intelligence who used traditional learning method and strategy. The study result is inconsistent with ${ }^{[43]}$ and ${ }^{[44]}$ who reported that the participants had a good score of emotional intelligence.

Otherwise, the present research indicated that majority of participants had an acceptable and adequate level of emotional intelligence, which is somehow in accordance with ${ }^{[45]}$ who conducted study of emotional intelligence and occupational burnout among nurses in critical care units in Tehran. The same findings were reported by ${ }^{[46]}$ who concluded that nursing students had fair emotional intelligence. Moreover, ${ }^{[4]}{ }^{[4]}$ specified that that nursing students had a moderate level of emotional intelligence. Besides, the study results parallels to ${ }^{[48]}$ who found that moderate to high levels of emotional intelligence among nurses, and high levels of caring behavior reflect on patient satisfaction and desire to come back to these hospitals.

Concerning emotional intelligence domains, the research finding displayed that the five domains of emotional intelligence were ranked as social skills, self-awareness, empathy, self- regulation and self-motivation from the highest to the lowest mean score. These findings match with ${ }^{[49]}$ who found nursing interns had a significant valuable percent in this deepest emotional intelligence competency. In the same context ${ }^{[50,51]}$ interpret this theme as the component of emotional intelligence that clarifies the recognizing of one's own feelings and those of others, motivating one and others, and managing emotions well with self-awareness and interacting with others, self-awareness should involve knowing when feelings are present in the self and others, and being able to label feelings with words expressing the specific feeling. Emotional intelligence, even though being an emerging concept, has given a new momentum to its relation to better performance both personal and professional ${ }^{[52]}$. Additionally, this finding was in accordance with ${ }^{[53]}$ who proved that the majority of nurses in Mansoura University Hospital had a proficient level in all components of emotional intelligence. Furthermore, the finding of the present study revealed that the most emotional intelligence nurse interns' behavior pertained to social skills. These findings highlight that nurse interns help others develop and shine, are excellent communicators, and are masters at building and maintaining relationships with their colleagues and others at work place beside their formal duties. In this regard, ${ }^{[54]}$ stated that social awareness was the most commonly demonstrated domain.

Results also revealed that the high level of professional behavior among Port Said nurse interns rather than their peers in Mansoura; this interprets the high level of emotional intelligence with Port Said nurses. Otherwise the two groups of participants behaved professionally, these results may be related to the feelings of nurse interns with their responsibility toward their profession and the constructive and continuous guidance follow-up from their preceptors and supervisors who behaves in a professional manner and act as role model in addition to their periodical evaluation that take a part for behavior and attitude, also it can be interpreted by the positive significant relation between psychological empowerment, emotional intelligence among nurse interns and their professional behavior. In this context, ${ }^{[55]}$ asserted that the new practitioner has the cognitive, behavioral skills and psychomotor, necessary to provide competent care.

Additionally, it is obvious from the study result that there was a statistically significant relation between psychological empowerment and professional behaviors; indicating that nurse interns who were empowered behaved in professional manner than not empowered. This is may be due to, nurse interns who had enough autonomy and felt a sense of control in relation to their work became competent in all tasks performed. This interpretation is supported by [11] who affirmed that psychological empowerment is a process that offers greater autonomy and decision-making to workers in all factors related to their work. This suggests that the process of granting greater autonomy and decision-making is given to someone as having competence or professionalism in the field of work, and the whole process will help the person to optimize their performance in conducting tasks, along with greater responsibility offered ${ }^{[9]}$. Nursing students who had the ability to establish a therapeutic relationship, autonomy over practice, control over the clinical practice environment, and the establishment of collaborative relationships had professional practice behavior ${ }^{[9]}$. Moreover, ${ }^{[36]}$ proved that the psychological empowerment has been seen as having the potential to assume a key role in the professional upgrading and development, increasing nurses' job satisfaction, providing a better quality for patients and 
included a sense of meaning, self-determination, competence and impact. In accordance with ${ }^{[56]}$ who claimed that empowerment has appeared to positively influence self-efficacy and professional practice behaviors in both students and registered nurses.

The present study proved a statistically significant relation between emotional intelligence components (self-awareness, self-motivation, empathy, and social skills) and professional behaviors. This finding goes in the same line with ${ }^{[57]}$ who asserted that emotional intelligence is a key component to being an effective and successful professional nurse. Also, ${ }^{[58]}$ clarified that individual performance is not only about doing tasks perfectly, but also about the capacity to control and deal with or manage oneself as well as about the ability to build relationships with others. These capabilities, called emotional intelligence which determines individual patterns of interaction and the quality of the relationships developed ${ }^{[25,26]}$. On a similar line,${ }^{[59]}$ illuminated that a set of specific skills, such as self-discipline, empathy, and initiative are the things individuals need to achieve outstanding success; these elements are called as emotional intelligence.

Finally, our study results revealed a statistically significant relation between psychological empowerment and emotional intelligence components (self-awareness, empathy, and social skills). Empowerment is becoming the main issue in the literature of the relationship between the culture of nursing and their participation ${ }^{[00]}$. These results can be clarified by ${ }^{[12,13]}$ theories which stated that empowerment is important in a way that it can make individuals do things that they beforehand could not do, including the capacity to perceive feelings, , manage emotions, motivate oneself, recognize feeling and emotions in others, and to build relationships with others, which is considered as emotional intelligence. These results in accordance with ${ }^{[9]}$ who found that psychological empowerment has a significant positive effect on emotional intelligence; this indicates that the one who perceive the higher level of psychological empowerment had the higher level of emotional intelligence. Moreover, ${ }^{[61]}$ found that psychological empowerment has a significant positive effect on emotional intelligence and employee performance. Furthermore, ${ }^{[62]}$ found that staff nurses' empowerment was strongly related to emotional intelligence components.

Generally, nurse interns should display proper behavior with the high level of competency and should act as emotionally intelligent person.

\section{Conclusion}

Study concluded that professional behavior is related to emotional intelligence and psychological empowerment. Nurse interns need to push forward from acceptable level of emotional intelligence to high level to be more effective and enhance their professional behavior and performance.

\section{The study recommends the following:}

\section{Recommendations}

- Enhancing and developing the professional self-concept for students are a basic need from the first stage, or early entering the nursing college.

- Appreciating and motivating nurse interns' real attitude toward the nursing profession and correcting it as best as they can.

- In the hospital, nurse managers should pay more attention to nurse interns' empowerment.

- Paying attention to the level of professional performance and behavior and keeping it to the high level through applying appropriate techniques, training, guidance and advice.

- Doing further studies about professional behavior challenges facing nurses' internship.

\section{Reference}

[1]. M. Laux, and C. Mc Intosh, Nursing Internships: Practicing Without a License, Journal of Nursing Regulation, 2(2), 2011, 37-39.

[2]. S.Winslow, M. Almarode, S. Nottingham, K. Kim Lowry, and K.Walker. New Graduates in the Emergency Department: Could You, Would You, Should You?, J Emerg Nurs, 35, 2009,521-4.

[3]. D. Edwards, C. Hawker, J.Carrier, and C.Rees, The effectiveness of strategies and interventions that aim to assist the transition from student to newly qualified nurse, JBI Library of Systematic Reviews, 9(53),2011, 2215-2323.

[4]. M. Terabit, S. M. Moghimi, and A. Monavarian, Investigating the Relation between Spiritual Intelligence and Psychological Empowerment among Nurses of Faghihi Hospital 2012, International Journal of Economy, Management and Social Sciences, 2(8), 2012, 539-543.

[5]. West, L. Loewenthal, R. Eckert , T .West, and A. Lee, Leadership and Leadership Development in Health Care: The Evidence Base, 2015, retrieved from: https://www.kingsfund.org.uk.

[6]. M .Thuss, Nursing Clinical Instructor Experiences of Empowerment in Rwanda: Applying Kanter's and Spreitzer's Theories, Master Thesis, 2014, retrieved from: http://ir.lib.uwo.ca/etd

[7]. I.E. Campbell, L. Larrivee, P.A. Field, R.A. Day, and L. Reutter, Learning to nurse in the clinical setting, Journal of Advanced Nursing, 20, 1994, 1125-1131.

[8]. Ergeneli, Azize, Güler Sag ${ }^{2}$ lam Arı, Selin Metin, Psychological empowerment and its relationship to trust in immediate managers, Journal of Business Research, 60, 2007, 41-49. 
[9]. I. Syech, A. Taher, M. Al Musadieq U. H. Nayati, The Effect of Psychological Empowerment on Self-Efficacy, Burnout, Emotional Intelligence, Job Satisfaction, and Individual Performance(An Empirical Study on Tour Guides in West Nusa Tenggara), European Journal of Business and Management, 7(8), 2015, 139-148.

[10]. S.N. Ambad, and M.A. Bahron, psychological Empowerment: The Influence on Organizational Commitment Among Employees in the Construction Sector, The Journal of Global Business Management ,8(2), 2012, 73-81.

[11]. R. Harsuko, Boosting Motivation and Performance, Empowerment Approach Human Resources, (UB Press. Malang, 2011).

[12]. D. Jenkins, Manging Empowerment: How to Make Business Reengineering Work (Cen-tury Limited, London, 1996).

[13]. D. Goldman, Emotional Intelligence. Heryana T (interpreter), tenth edition (Gramedia Pustaka Umum, Jakarta, 2000).

[14]. B.L.Marquis, and C.J. Huston, Leadership roles and management functions in nursing: Theory and application (7th ed.) (Philadelphia: Lippincott Williams\& Wilkins, 2012).

[15]. J. M. Antony, The influence of emotional intelligence on organizational commitment and organizational citizenship behavior, International Journal of Social Science \& Interdisciplinary Research, 2 (3), 2013, 110-115.

[16]. K.Hefferon, and I.Boniwe, Positive psychology: Theory, research and application (UK: The McGraw-Hill Companies Inc., 2011).

[17]. P. Kelly, and J. Tazbir, Essential of nursing leadership and management ( $3^{\text {rd }}$ ed.) (U.S.A: Delmar Cengage Learning, 2014).

[18]. R.P. Jones, Nursing leadership and management: Theories, processes and practice (. USA: F. A. Davis Company, 2007).

[19]. V. Gokenbach, Professionalism in Nursing: What Does It Really Mean? Retrieved from www.nursetogether.com/professionalismin-nursing-what-does-it-re. Accessed Access 5-6 at 1 a.m.

[20]. K.S. Bang, J.H. Kang, M.H. Jun, H.S .Kim, H.M .Son, and J.Yu Su, Professional values in Korean undergraduate nursing students, Nurse Education Today, 3 (1), 2011,72-5.

[21]. S. A. Ibrahim, and S. A .Qalawa, Relationship between faculty staff professionalism and nursing students' values, Journal of Nursing Education and Practice, 6(9), 2016, 38-45.

[22]. H .Altiok, and B. Üstün, Meaning of Professionalism in Nursing Students, American International Journal of Social Science, 3(6), 2014, 48-60

[23]. M.N. Björkström, A.A .Athlin, and I.S. Johansson, Nurses' development of professional self - from being a nursing student in a baccalaureate program to an experienced nurse, Journal of Clinical Nursing,17 (10), 2008, 1380-1391.

[24]. College and Association of Registered Nurses of Alberta (CARNA), Professional Boundaries for Registered Nurses Guidelines for the Nurse-Client Relationship, Canada, 2011, 3-4.

[25]. D. S. Bell, Emotional intelligence for the authentic and diverse workplace (U.S.A: Library of congress, 2011).

[26]. J. S. Parbury, Patient and person: Interpersonal skills in nursing (5th ed.) (Australia: Churchill Livingstone Elsevier, 2014).

[27]. G.M. Spreitzer, Social structural characteristics of psychological empowerment, Academy of Management Journal, 39, 1996, 483504.

[28]. S .A.Ibrahim, Factors affecting assertiveness among student nurses, Nurse Education Today, 31(4), 2011, 356-360.

[29]. J. Manktelow, K. Jackon, S. Edwards, E. Eyre, L. Cook, and B. Khan, How Emotionally Intelligent Are You? Boosting Your People Skills, 2016, Available at https://www. Mind tools.com.

[30]. F. Goz, and E. Geckil, Nursing students professional behaviors scale (NSPBS) validity and reliability, Pak J Med Sci , 26(4), 2010, 938-941.

[31]. K .Casey, R. Fink, and M. Krugman, The Graduate Nurse Experience. Journal of Nursing Administration, 34(6), 2004, 303-3011. PMID: 15190226. http://dx.doi.org/10.1097/00005110-200406000-00010

[32]. B. D. Christens, toward relational empowerment, American Journal of Community Psychology, 50(1-2), 2012, 114-128.

[33]. PMid: 22094588 http://dx.doi.org/10.1007/s10464-011-9483-5

[34]. G.M. Spreitzer, "Psychological empowerment in the workplace: dimensions, measure-ment, and validation", Academy of Management Journal, 38(5), 1995, 1442-1465.

[35]. B. Marquis, and C. Huston, Leadership roles and management functions in nursing: Theory and application, 8th Ed (Philadelphia: Wolters Kluwer Health, 2015).

[36]. H.K.S. Laschinger, Gilbert, L.M. Smith, and LeslieK. Towards a Comprehensive Theory of Nurse/Patient Empowerment: Applying Kanter's Empowerment Theory to Patient Care, Journal of Nursing Management. (18), 2010, 4-13. PMid: 20465724 http://dx.doi.org/10.1111/j.1365-2834.2009.01046.x

[37]. M.A. Corbally, P.A. Scott, A. Matthews, L.M. Gabhann, and Murphy, Irish Nurses' and Midwives' Understanding and Experiences of Empowerment, Journal of Nursing Management, 15, 2007, 169-179. PMid: 17352700 http://dx.doi.org/10.1111/j.13652834.2007.00626.x

[38]. American Association of Critical Care Nurses, AACN Position Statement on Moral Distress, 2012. Available from: (http://www.aacn.org/WD /practice/Docs/Moral_Distress.pdf. Accessed December 4, 2012.

[39]. M. Ibrahim, M. Abo El-Magd, and H. Sayed, Nurse's psychological empowerment and perceived autonomy in university and teaching hospitals at Menofia Governorate/Egypt, Journal of Nursing Education and Practice, 4 ( 9), 2014, 59-68.

[40]. A. Nasiripour, and S. Siadati, A Propose Model for Nurses Empowerment through Characteristics of Workplace and Management Strategies; A Study in Iranian Hospitals, Australian Journal of Basic and Applied Sciences, 5(6), 2011, 906-911.

[41]. M.W. Eysenck, and M. Kean, Cognitive psychology ( Hoveand New York: Psychology Press, 2005).

[42]. P. Catherine, Perceived permanentrating of casino key account representatives, Master Dissertation, Victoria University, 2008.

[43]. Z. Arefnasab, H. Zare, and A. Babamahmoodi, Emotional intelligence and problem solving strategy: a comparative study based on "Tower of Hanoi" test, Iran J Psychiatry Behave Sci, 6(2), 2012, 62- 68.

[44]. H. Namdar, M. Sahebihagh, H. Ebrahimi,and A .Rahmani, Assessing emotional intelligence and its relationship with demographic factors of nursing students, Iranian Journal of Nursing and Midwifery Research, 13(4), 2008,145-149.

[45]. J. Por, L. Barriball, J. Fitzpatrick, and J. Roberts, Emotional intelligence: Its relationship to stress, coping, well-being and professional performance in nursing students, Nurse Educ Today, 31(8), 2011, 855-60. Doi: 10.1016/j. nedt.2010.12.023

[46]. M.Delpasand, A. Nasiripoor, P. Raiisi, M. Shahabi, The relationship between emotional intelligence and occupational burnout among nurses in critical care, IJCCN, 4(2), 2011, 79-86.

[47]. E. Senyuva, H. Kaya, B. Isik, and G. Bodur, Relationship between self-compassion and emotional intelligence in nursing students, International Journal of Nursing Practice, 20, 2014, 588-596.

[48]. G. Benson, J. Ploeg, and B. Brown, A cross-sectional study of emotional intelligence in baccalaureate nursing students, Nurse Educ Today, 30(1), 2010, 49-53. doi: 10.1016/j. nedt.2009.06.006

[49]. D. Kaur, M. Sambasivan, and N. Kumar, Significance of Spiritual (SI) and Emotional Intelligence (EI) on the Caring Behavior of Nurses, J Comm Pub Health Nursing, 1 (2), 2015, 1-3.

[50]. A. F. Ibrahim, D.T. Akel, L. A. Abd El Fatah, and M.O. Abudari, Emotional intelligence and internet addiction among nursing interns, Clinical Nursing Studies, 4(1), 2016,70-80. 
[51]. S. Hein, EQ for everybody: A Practical Guide to the Developing and using one's Emotional Intelligence, 3rd Ed, 2012.

[52]. B. Ibrahim, Internet Addiction and Psychological Morbidity among Nursing Students in Gaza-Palestine, American Journal of Applied Psychology, 3(4), 2014, 99-103.

[53]. M. A. Nair, and P. Lee, Emotional Intelligence in Nursing, IOSR Journal of Nursing and Health Science, 5(6), 2016, 38-42.

[54]. S.H. Helaly, Emotional intelligence and its relation to nursing performance among nurses at Mansoura university hospital and urology and nephrology center ,Unpublished Doctorate's thesis., Mansoura University, Egypt, 2013.

[55]. B.M. Kooker, J. Shoultz, and E.E. Codier, Identifying emotional intelligence in professional nursing practice, Journal of Professional Nursing, 23(1), 2007, 30-36. Retrieved from: http://www.sciencedirect.com

[56]. D.U. Jette, and L. G. Portney, Construct Validation of a Model for Professional Behavior in Physical Therapist Students, Journal of the American physical therapy association, 83(5), 2003, 432-443. Available at http://ptjournal.apta.org

[57]. H. K. Laschinger, Effect of empowerment on professional practice environments, work satisfaction, and patient care quality: further testing the Nursing Work life Model, Journal of Nursing Care Quality, 23, 2008, 322-330.

[58]. R. S. Nadler, Leading with emotional intelligence: Hands on strategies for building confident and collaborative star performers (New York: The McGraw-Hill Companies, 2011).

[59]. J.P. Meyer, T.E. Becker, and C. Vandenberghe, "Employee commitment and motivation: A conceptual analysis \& integrative model", Journal of Applied Psychology, 89, 2004, 991-1007.

[60]. D.C.McClelland, Business Leadership Training Program. Book I (McBer \& Compa-ny. Massachusetts, 1974).

[61]. J.T. Knol, Mede werker participatie ende cultuur binnen de verpleging - een literatuurstudie. Unpublished literature study, Utrecht University, 2006.

[62]. G. Meyerson, and B. Dewettinck, "Effect of Empowerment on Employees Per formance", Advanced Research in Economic and Management Sciences, 2, 2012, 40-46.

[63]. V. Lucas, H.K. laschinger, and C.Wong, The impact of emotional intelligent leadership on staff nurses empowerment: The moderating effect of span of control. Journal of Nursing Management, 16(8), 2008, 964-973.Retrieved from: http://www.onlinelibrary.wiley.com 